\title{
Chronology for climate change: Developing age models for the Biogeochemical Ocean Flux Study cores
}

\author{
B. Manighetti and I.N. McCave \\ Department of Earth Sciences, University of Cambridge, Cambridge, England
}

M. Maslin

Geologisch-PalaontologischesInstitut, Universitat Kiel, Kiel, Germany

N. J. Shackleton

Godwin Laboratory, University of Cambridge, Cambridge, England

\begin{abstract}
We construct age models for a suite of cores from the northeast Atlantic Ocean by means of accelerator mass spectrometer dating of a key core, BOFS 5K, and correlation with the rest of the suite. The effects of bioturbation and foraminiferal species abundance gradients upon the age record are modeled using a simple equation. The degree of bioturbation is estimated by comparing modeled profiles with dispersal of the Vedde Ash layer in core $5 \mathrm{~K}$, and we find a mixing depth of roughly $8 \mathrm{~cm}$ for sand-sized material. Using this value, we estimate that age offsets between unbioturbated sediment and some foraminifera species after mixing may be up to 2500 years, with lesser effect on fine carbonate $(<10 \mu \mathrm{m})$ ages. The bioturbation model illustrates problems associated with the dating of "instantaneous" events such as ash layers and the "Heinrich" peaks of ice-rafted detritus. Correlations between core $5 \mathrm{~K}$ and the other cores from the BOFS suite are made on the basis of similarities in the downcore profiles of oxygen and carbon isotopes, magnetic susceptibility, water and carbonate content, and via marker horizons in $\mathrm{X}$ radiographs and ash beds.
\end{abstract}

\section{Introduction}

Recent advances in the understanding of oceanographic changes over the last $30 \mathrm{ka}$ have been possible, partly as a result of improvements in stratigraphic resolution brought about by development of accelerator mass spectrometer (AMS) radiocarbon dating. Work on a $<30,000$ year timescale demands a very tight age control and precise correlation if robust inferences are to be made about rapid changes or events of short duration. The basic requirements are a continuous depositional record and rapid sedimentation to minimize the effects of bioturbation. This study deals with the development of an AMS-based age model for a core from the Biogeochemical Ocean Flux Study (BOFS) suite and the application of the age model to other BOFS cores by correlation.

\section{Location}

The BOFS northem leg coring was carried out in 1989 on RRS Discovery cruise 184 [McCave, 1989], along a transect at approximately $20^{\circ} \mathrm{W}$, from the lower flanks of the MidAtlantic Ridge at $47^{\circ} \mathrm{N}$ and the East Thulean Rise, across the South Rockall Gap, along the slopes of Rockall Bank, over

Copyright 1995 by the American Geophysical Union.

Paper number 94PA03062

0883-8305/95/94PA-03062\$10.00 the Hatton-Rockall Basin and South Iceland Basin to Gardar Drift at $59^{\circ} \mathrm{N}$. Fifteen kastenlot cores were recovered using a 3-m corer barrel designed by Zangger and McCave [1990], of which nine are included in this study. Their location, depth and recovered lengths are given in Table 1 . Subsamples from five of the cores $(5 \mathrm{~K}, 8 \mathrm{~K}, 11 \mathrm{~K}, 14 \mathrm{~K}$ and $17 \mathrm{~K})$ were analyzed for oxygen and carbon isotopes at the Godwin Laboratory, Cambridge, and based upon these results, core 5K was selected for AMS dating. Each core was subsectioned, $X$ rayed, probed for bulk magnetic susceptibility and sampled to determine water content. Wet sieving yielded the proportions greater and less than $63 \mu \mathrm{m}$, and magnetic susceptibility was then measured on the coarse and fine fractions. Total- and carbonate-carbon analysis was carried out on the whole sediment and the fine fraction (see also Manighetti and $M c$ Cave, this issue).

\section{Methods}

AMS ${ }^{14} \mathrm{C}$ dating was carried out on monospecific samples of the planktonic foraminifera Globigerina bulloides, Neoglobigerina pachyderma (s) and Globorotalia inflata by M. Amold and J-C Duplessy at Gif-sur-Yvette. G. bulloides and $G$. inflata samples were picked from the 300-355 $\mu \mathrm{m}$ fraction and $N$. pachyderma (s) from the the $250-300 \mu \mathrm{m}$ fraction. Oxygen and carbon stable isotopic measurements were made at Cambridge on VG Sira Series 11 and Prism mass 
Table 1. Details of Core Locations

\begin{tabular}{lrrrr}
\hline $\begin{array}{l}\text { Discovery } \\
\text { Station }\end{array}$ & Core & Latitude & Longitude & $\begin{array}{l}\text { Water } \\
\text { Depth, m }\end{array}$ \\
\hline $11882 / 4$ & $5 \mathrm{~K}$ & $50^{\circ} 40.9^{\prime} \mathrm{N}$ & $21^{\circ} 52.0^{\prime} \mathrm{W}$ & 3547 \\
$11883 / 3$ & $6 \mathrm{~K}$ & $51^{\circ} 07.0^{\prime} \mathrm{N}$ & $21^{\circ} 11.9^{\prime} \mathrm{W}$ & 2865 \\
$11884 / 4$ & $7 \mathrm{~K}$ & $51^{\circ} 45.3^{\prime} \mathrm{N}$ & $22^{\circ} 32.5^{\prime} \mathrm{W}$ & 2327 \\
$11886 / 2$ & $8 \mathrm{~K}$ & $5^{\circ} 30.1^{\prime} \mathrm{N}$ & $22^{\circ} 04.2^{\prime} \mathrm{W}$ & 4045 \\
$11889 / 2$ & $9 \mathrm{~K}$ & $5^{\circ} 41.6^{\prime} \mathrm{N}$ & $21^{\circ} 19.5^{\prime} \mathrm{W}$ & 3268 \\
$11890 / 2$ & $10 \mathrm{~K}$ & $54^{\circ} 39.9^{\prime} \mathrm{N}$ & $20^{\circ} 39.0^{\prime} \mathrm{W}$ & 2777 \\
$11891 / 4$ & $11 \mathrm{~K}$ & $55^{\circ} 11.5^{\prime} \mathrm{N}$ & $20^{\circ} 21.1^{\prime} \mathrm{W}$ & 2004 \\
$11896 / 1$ & $14 \mathrm{~K}$ & $58^{\circ} 37.2^{\prime} \mathrm{N}$ & $19^{\circ} 26.2^{\prime} \mathrm{W}$ & 1756 \\
$11905 / 1$ & $17 \mathrm{~K}$ & $5^{\circ} 00.2^{\prime} \mathrm{N}$ & $1^{\circ} 29.8^{\prime} \mathrm{W}$ & 1150 \\
\hline
\end{tabular}

spectrometers [see Shackleton and Hall, 1989]. Bulk magnetic susceptibility was measured with a Bartington Instruments MS2 meter and a probe-type sensor held against sediment slabs. Coarse and fine fraction magnetic susceptibility was also measured on dried samples using a Bartington MS2B sensor with a 36-mm internal diameter. Total, carbonate and organic carbon contents were determined using a Carlo Erba 1106 elemental analyzer, according to the method of Manighetti [1993], and grain size distributions were investigated by wet sieving at $63 \mu \mathrm{m}$ followed by analysis on a SediGraph 5000 ET with a computer interface devised by Jones et al. [1988].

\section{Developing an Age Model for Core 5K}

\section{AMS Dating}

The age model for the northem BOFS core suite is based upon AMS dating of core 5K from the East Thulean Rise. In addition to good resolution of features in its oxygen isotopic profiles, core 5K possesses distinct correlatable horizons such as the Vedde Ash and deposits of the latest four icerafting pulses known as "Heinrich events" [Heinrich, 1988; Broecker et al., 1992]. The AMS dates on BOFS 5K are shown in Table 2, and plotted against depth downcore in Figure 1.

The ${ }^{14} \mathrm{C}$ dates in Table 2 were calculated using the Libby half life of 5568 years, and converted to "calendar ages" using the marine calibration datasets of Stuiver and Braziunas [1993] and Bard et al. [1993a] with the program Calib-3.0 [Stuiver and Reimer, 1993]. The Stuiver and Braziunas [1993] dataset incorporates a time-dependent world ocean reservoir correction averaging 409 years, back to $11,400 \mathrm{cal}$ B.P.. The Bard et al. [1993a] calibration of ages between 11,400 and $21,950 \mathrm{cal}$ B.P. is based on coral samples which record the local regional (and variable) reservoir deficiency of unknown magnitude (but often estimated at a constant 400 years). Beyond 21,950 years B.P., there is insufficient evidence for a detailed calibration of ${ }^{14} \mathrm{C}$ to calendar years, but sparse coral data indicate that the offset is at least as large at $30 \mathrm{ka}$ as at 20 ka (Paula Reimer, personal communication, 1993]. Older ${ }^{14} \mathrm{C}$ dates have therefore been "calibrated'" by applying a constant offset, of +3182 years, representing both the difference due to ${ }^{14} \mathrm{C}$ activity changes, the reservoir correction

Table 2. Accelerator Mass Spectrometer Dates for Core 5K

\begin{tabular}{|c|c|c|c|c|c|}
\hline $\begin{array}{c}\text { Depth, } \\
\text { cm }\end{array}$ & Foram Species & $\begin{array}{r}\text { Marine } \\
{ }^{14} \mathrm{C} \text { Age }\end{array}$ & $1 \sigma$ Error & $\begin{array}{l}\text { Estimated } \\
\text { Atmospheric } \\
{ }^{14} \mathrm{C} \text { Age }\end{array}$ & $\begin{array}{c}\text { Calibrated } \\
\text { Age }\end{array}$ \\
\hline 0 & G. bulloides & 2,020 & 140 & 1,620 & 1,556 \\
\hline 20 & G. inflata & 4,970 & 130 & 4,570 & $5,292^{\text {a }}$ \\
\hline 38 & G. bulloides & 8,860 & 130 & 8,460 & $9,462^{a}$ \\
\hline 44 & G. inflata & 14,970 & 180 & 14,570 & 17,447 \\
\hline 46 & G. bulloides & 11,180 & 150 & 10,780 & $12,709^{b}$ \\
\hline 46 & N. pachyderma (s) & 10,770 & 130 & 10,370 & $12,257^{b}$ \\
\hline 73 & G. bulloides & 12,860 & 150 & 12,460 & 14,590 \\
\hline 74 & G. bulloides & 12,990 & 160 & 12,590 & 14,781 \\
\hline 74 & N. pachyderma $(\mathrm{s})$ & 15,370 & 180 & 14,970 & $17,884^{a}$ \\
\hline 78 & N. pachyderma (s) & 16,520 & 180 & 16,120 & 18,995 \\
\hline 80 & N. pachyderma (s) & 16,510 & 170 & 16,110 & $18,985^{a}$ \\
\hline 90 & N. pachyderma (s) & 17,650 & 220 & 17,250 & $20,472^{a}$ \\
\hline 100 & N. pachyderma (s) & 20,210 & 280 & 19,810 & $23,392^{a}$ \\
\hline 114 & N. pachyderma (s) & 22,960 & 330 & 22,560 & $26,142^{a}$ \\
\hline 130 & N. pachyderma (s) & 25,300 & 400 & 24,900 & $28,482^{a}$ \\
\hline 148 & N. pachyderma (s) & 28,800 & 530 & 28,400 & $31,982^{\mathrm{a}}$ \\
\hline 202 & G. bulloides & 35,500 & 1100 & 34,800 & $38,682^{c}$ \\
\hline 202 & $N$. pachyderma (s) & 35,200 & 1000 & 35,100 & $38,382^{c}$ \\
\hline 238 & N. pachyderma (s) & 30,440 & 630 & 30,040 & 33,622 \\
\hline
\end{tabular}

\footnotetext{
- Date used in age model

b Average of these dates used as $46 \mathrm{~cm}$ age

c Average of these dates is used as $202 \mathrm{~cm}$ age
} 


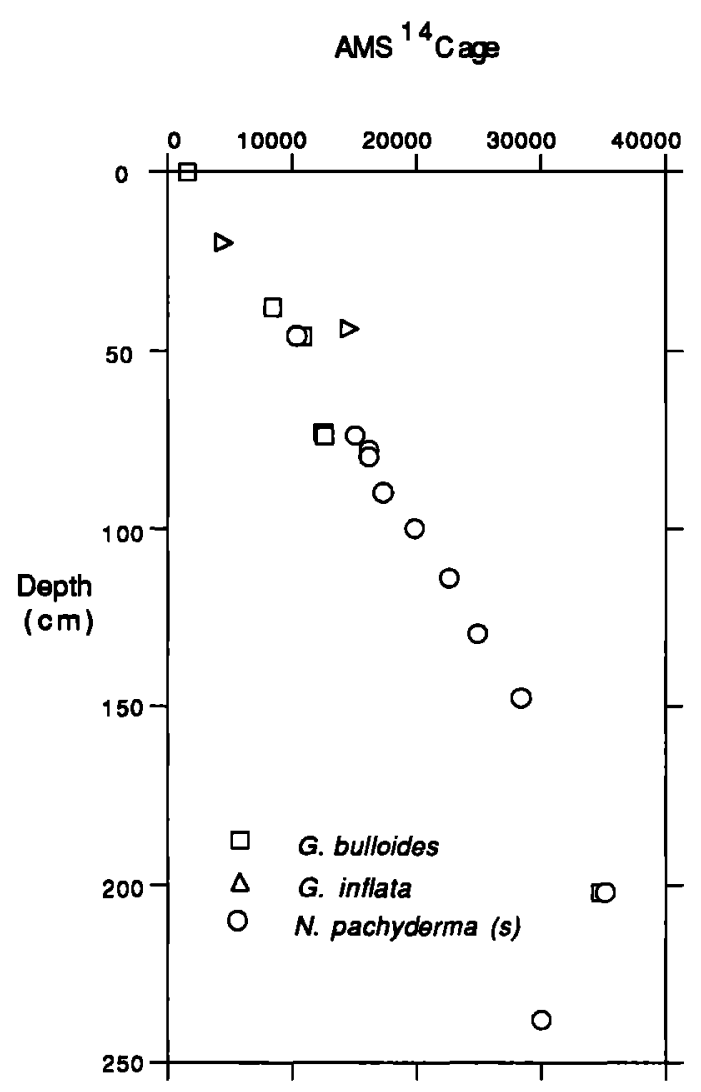

Figure 1. AMS ${ }^{14} \mathrm{C}$ ages against depth in core $5 \mathrm{~K}$. Dates determined on $G$. bulloides samples are shown as squares, while $N$. pachyderma (s) dates are shown as circles and $G$. inflata as triangles.

for marine samples, and a correction taking account of the use of the Libby half life rather than the true value of 5730 years.

It is not feasible to use every date in Table 2 to create the age model, since age inversions occur and dates determined on different species at the same depth interval may differ widely. As suggested by Broecker et al. [1984] and demonstrated by Andree et al. [1984], Peng and Broecker [1984] and Bard et al. [1987], in the presence of species-abundance gradients, age biases may be generated, particularly where accumulation rates are low. By considering what is known of planktonic foraminiferal species abundance in the area through time, and the mechanism of bioturbation, it is possible to determine which dates are the most reliable.

\section{Species Abundance and Bioturbation}

It has been widely documented that the abundance of the species $N$.pachyderma (s) changes between glacial and interglacial times in Atlantic sediments of middle latitudes [e.g. Ruddiman and McIntyre, 1976; Ruddiman et al., 1977; Bard et al., 1987; Broecker et al., 1988a]. It is the single planktonic foraminifera with a preference for polar waters [Kipp, 1976], and therefore an indicator of low temperatures in surface waters. In parts of the North Atlantic, it reached almost $100 \%$ of the total planktonic foraminifera count $(>150 \mu \mathrm{m})$ during glacial times [Ruddiman and McIntyre,
1981; Maslin, 1993]. In warmer periods, however, it is largely replaced by an assemblage of subpolar and transitional species, including $G$. bulloides and $G$. inflata. The abundance of $N$. pachyderma (s) and $G$. bulloides with depth in core $5 \mathrm{~K}$ is shown in Figure 2.

If the abundance of a species used for radiocarbon dating changes with depth downcore, then bioturbation will introduce age biases in the portion of the record where the gradient occurs. An example of such a gradient occurs in the records of the species $N$. pachyderma. (s) and $G$. bulloides across Termination 1 (Figure 2), and may explain the large discrepancy ( 3100 calendar years) between the ages measured on these two species at $74 \mathrm{~cm}$ (Figure 2). The glacial abundance of $G$. bulloides is usually under $1 \%$ while $N$. pachyderma (s) is as high as $16 \%$, as a weight percentage of total sediment. In the Holocene, the abundance of $G$. bulloides rises to $\sim 2-4 \%$, while $N$. pachyderma falls to below $1 \%$. Mixing of sediment across the Termination will introduce relatively abundant, younger $G$. bulloides to older, bulloides-poor levels further down. By contrast, fewer young $N$. pachyderma will be mixed down from above the termination, where they are scarce, so that the $N$. pachyderma (s) date is likely to be more reliable.

For the purpose of flux calculations, the age model must give a zero age for the sediment surface, rather than an average age of the mixed layer (dated 1556 calendar years on a $G$. bulloides sample from the uppermost centimetre of the core). However, it may be incorrect to assign a zero age to the core top, since during recovery of kastenlot cores, a small amount of material is usually lost. The core top age is therefore estimated by extrapolating the sedimentation rate between two Holocene dated points $(20$ and $38 \mathrm{~cm}$ ) upward to give a surface intercept of 659 calendar years. At a sedimentation rate of $4.32 \mathrm{~cm} \mathrm{ka}^{-1}$, this implies a loss from the core top of $2.85 \mathrm{~cm}$, which seems a reasonable estimate of the recovery of surfaces in kasten coring. Assuming homogeneity, the present mixed layer can be estimated at about $7 \mathrm{~cm}$.

The $G$. inflata date at $44 \mathrm{~cm}$ (17447 calendar years) is anomalous, significantly higher than dates immediately below, and apparently about $5 \mathrm{ka}$ too old. The very large amount of older material required to produce such a discrepancy probably precludes contamination as the cause of the error. It is also unlikely that the sample interval was wrongly identified, since the abundance of $G$. inflata remains below picking levels through the glacial until around $64 \mathrm{~cm}$, corresponding to roughly $15.5 \mathrm{ka}$ based on other AMS dates in the core. At $17.5 \mathrm{ka}$ there are hardly any $G$. inflata present. For this reason too, bioturbation could not account for the result, and we cannot satisfactorily explain the anomaly. At $46 \mathrm{~cm}$, the dates on $G$. bulloides and $N$. pachyderma (s) coincide within $2 \sigma$ errors (Table 2 ), both species are at similar levels of abundance (Figure 2), although $N$. pachyderma is on the decline, and might be expected to generate an older date than $G$. bulloides, whose abundance is roughly constant. An average of the two dates is used for the $46 \mathrm{~cm}$ horizon in the $5 \mathrm{~K}$ age model.

At 78 and $80 \mathrm{~cm}$, two $N$. pachyderma (s) dates fall within 10 years of each other, and the date at $80 \mathrm{~cm}$ is included in the model since it lies more directly on the age-depth trend in 

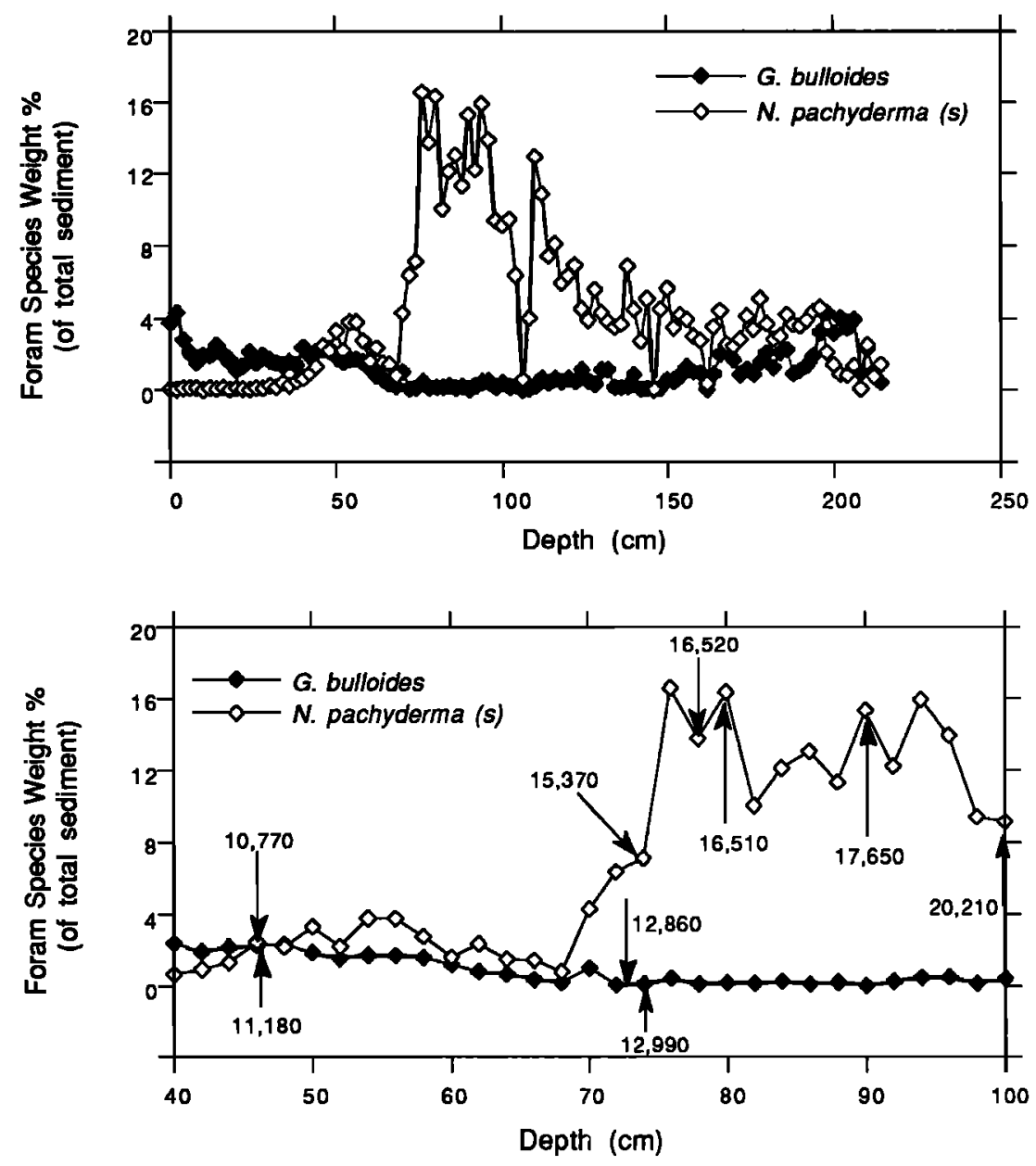

Figure 2. Abundance of the foram species $G$. bulloides and $N$. pachyderma (s) with depth in core $5 \mathrm{~K}$, expressed as a weight percentage of the total sediment. Detail of the interval $40-100 \mathrm{~cm}$ shows the location of AMS ${ }^{14} \mathrm{C}$ dated samples on the abundance curves, and the large offset between $G$. bulloides and $N$. pachyderma (s) ages at $74 \mathrm{~cm}$.

Figure 1. The $N$. pachyderma (s) age at $238 \mathrm{~cm}$ lies well off the main trend in Figure 1 , and is reversed with respect to $G$. bulloides and $N$. pachyderma ages from $202 \mathrm{~cm}$. This is presumably a result of contamination with younger material, which causes relatively greater errors as sample age increases. This date, and that of the $G$. inflata sample at $44 \mathrm{~cm}$, are not included in the age model.

The age model was constructed by linear interpolation between the chosen eleven calibrated AMS dates and inferred core top age, and extended below $202 \mathrm{~cm}$ by using the average sedimentation rate in the core $\left(5.33 \mathrm{~cm} \mathrm{ka}^{-1}\right.$ calendar years, $0-202 \mathrm{~cm}$ ). The model is illustrated in Figure 3 showing calibrated age versus depth, and giving the sedimentation rates over different segments of the record. This model minimises the impact of bioturbation of steep abundance gradients on age estimates. Nevertheless, these gradients are present, both in the foraminiferal abundances and several other properties. We therefore wish to assess the likely magnitude of age offsets due to bioturbation, and in the next section examine this problem using a simple homogenous mixing model.

\section{Bioturbation: A Simple Model}

In the simplest type of bioturbation model, mixing takes place within the sediment to a given depth, and is assumed to completely homogenize the "bioturbation box" within a timescale short relative to the sedimentation rate [Berger and Heath, 1968]. The mechanism of bioturbation is as described by $B$ ard et al. [1987] in their attempt to deconvolve isotopic records for the last deglaciation, and contains no diffusion gradent. The following development reaches the same conclusion as Bard et al. [1987] in a simple arithmetical manner.

Consider a sediment column which is homogenously mixed to a depth $H$, with a concentration of a particular foram species $\mathrm{C}_{0}$ orig. Sediment is added to the column in increments corresponding to the thickness of the sampling interval $x$. The new sediment has a concentration of the foraminiferal species, $\mathrm{C}_{\mathrm{a}}$ orig. This is then mixed thoroughly with underlying material to a depth of $H$, producing a homogenous layer with a concentration of the foram species $C_{1}{ }^{\text {new }}$. A homogenous layer of $\mathrm{C}_{0}{ }^{\circ}, x$ thick, remains below the new mixed layer. 


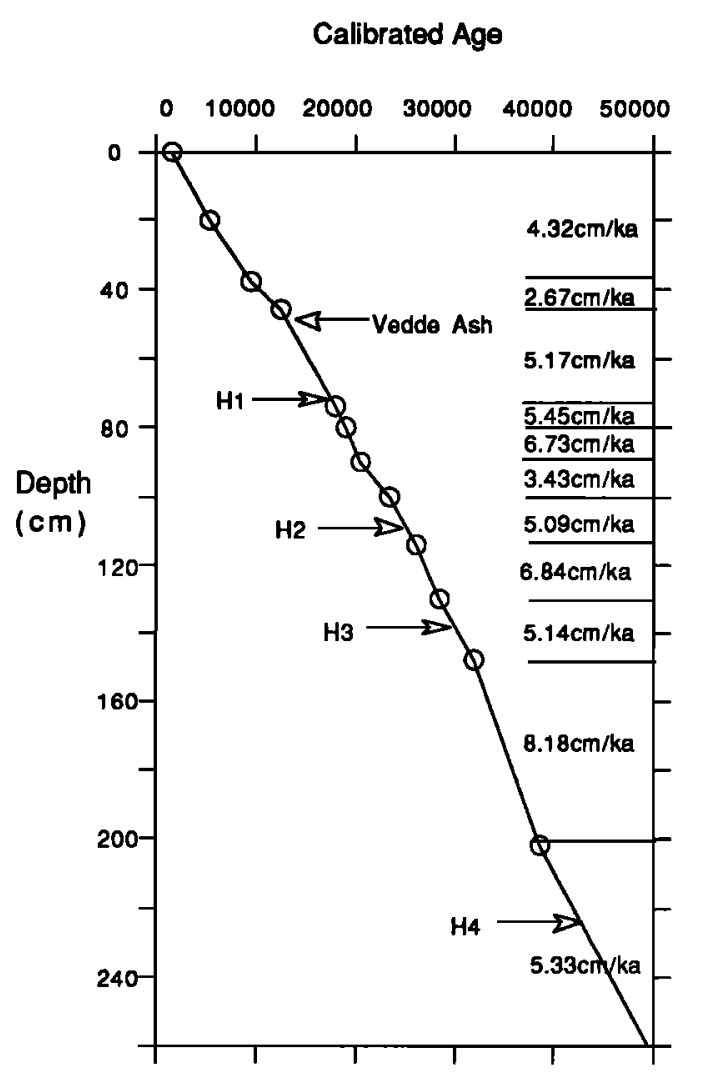

Figure 3. Calibrated age model for core $5 \mathrm{~K}$, based upon AMS ${ }^{14} \mathrm{C}$ dates selected as described in text. The position of the Vedde Ash and Heinrich events 1-4 are marked.

New increments are continually added to the column, building up a pile of homogenously mixed layers. This may be expressed as follows:

The measured (bioturbated) value of foraminiferal abundance in increment $y$ is given by

$$
C^{n} y=\left(\frac{x}{H}\right) C^{o} y+[(H / x)-1]+\left(1 \frac{x}{H}\right) C^{n} y-1
$$

and the "original" value of foraminiferal abundance in the same interval is

$$
\mathrm{C}^{O}{ }_{y}=\frac{\mathrm{C}_{y-[(H / x)-1]}^{n}}{(x / H)}-\frac{\left(1 \frac{x}{H}\right) C^{n}{ }_{y-(H / x)}}{(x / H)}
$$

which may be rearranged to

$$
\mathrm{C}^{O}{ }_{y}=(H / x) \mathrm{C}^{n}{ }_{y-(H / x)+1}+[1-(H / x)] \mathrm{C}^{n}{ }_{y-(H / x)}
$$

As shown by Bard et al. [1987], an AMS age record or isotopic signal can be deconvolved simply by working with the product: (carrier concentration times age) or (carrier concentration times isotopic ratio)

Because of the small number and wide spacing of the AMS dates, deconvolution cannot be carried out on the measured AMS-dated intervals alone. However, it would be misleading to attempt a deconvolution of linearly interpolated age models based on $G$. bulloides and $N$. pachyderma (s) dates, since it is highly unlikely that following bioturbation in the presence of species abundance gradients, ages would maintain linearity. What is more revealing is to assess whether a linear age sequence can be theoretically "bioturbated" to produce offsets of over 3000 years, given the observed species abundance changes downcore, and by employing a realistic mixing depth. To determine the characteristic mixing depth for sandsized material in BOFS $5 \mathrm{~K}$, we examined the dispersal of coarse fraction sediment from an instantaneously deposited layer, the Vedde Ash [Mangerud et al., 1984].

In Figure 4a, the number of sand-sized rhyolitic shards per gram of total sediment is plotted against depth downcore. The bioturbated ash profile in core $5 \mathrm{~K}$ is asymmetrical, with a fairly sharp base and gradational top. This resembles the curve generated by simple model bioturbation, although the base is more diffuse than the model predicts. By plotting the natural log of ash abundance against depth, the observed curve may be compared with theoretical homogenous bioturbation of an ash layer with different values of $H$ (the bioturbation depth) and a sampling interval $x=2 \mathrm{~cm}$ (Figures $4 \mathrm{~b}$ and $4 \mathrm{c}$ ). As $H$ increases, the gradient of the $\log$ abundance line decreases in the model, in a manner which enables the characteristic value of $H$ to be estimated for the $5 \mathrm{~K}$ ash profile. In $5 \mathrm{~K}$, the best fit line through the log data has a gradient of 0.162 and corresponds most closely to theoretical bioturbation using a mixing depth $H=8 \mathrm{~cm}$. This is typical for deep marine environments [Nozaki et al., 1977; Peng et al., 1977] and similar to the mixing depth determined for the Holocene by bulk ${ }^{14} \mathrm{C}$ and ${ }^{210} \mathrm{~Pb}_{\text {excess }}$ profiles on BOFS box core samples [Thomson et al., 1993a, b], suggesting that the assumption of homogenous bioturbation to a constant depth below the surface is a reasonable first approximation.

This study also illustrates the problem associated with the use of "instantaneous" marker horizons for age modeling purposes. With a mixing depth of $8 \mathrm{~cm}$, an ash layer deposited at $\boldsymbol{n}$ centimetres in a core will appear at peak abundance $n-H \mathrm{~cm}(8 \mathrm{~cm})$ below its original position, following bioturbation (Figure 4d). The age of the ash layer measured on land (in deposits not subject to bioturbation) is therefore unlikely to correspond to the age of foraminifera mixed in with the ash in marine deposits, since the abundance of foraminifera used for dating does not vary as markedly as the ash grains. The problem is much more acute, of course, in cores with a low sedimentation rate: at an average of $2 \mathrm{~cm} \mathrm{ka}^{-1}$, an $8 \mathrm{~cm}$ displacement makes a difference of 4000 years, whereas at $20 \mathrm{~cm} \mathrm{ka}^{-1}$, the difference is only 400 years.

To investigate the possible effects of homogenous bioturbation to a depth of $8 \mathrm{~cm}$ on the ages recorded by $N$. pachyderma (s) and $G$. bulloides, it is first necessary to "deconvolve" the species abundances, using equation 3 (Figure 5). A simple, linear age sequence is then 'bioturbated' with each of the restored species abundance profiles. This yields two separate age models, one for each species, which can then be compared with the "true age" at any depth. The method was attempted using $5 \mathrm{~K}$ species abundance data and a linear age model from zero to 28,482 years, the (calibrated) age recorded by a $N$. pachyderma (s) sample at $130 \mathrm{~cm}$ depth. For modelling purposes, this age was assumed to have remained unchanged following bioturbation. In certain cases 

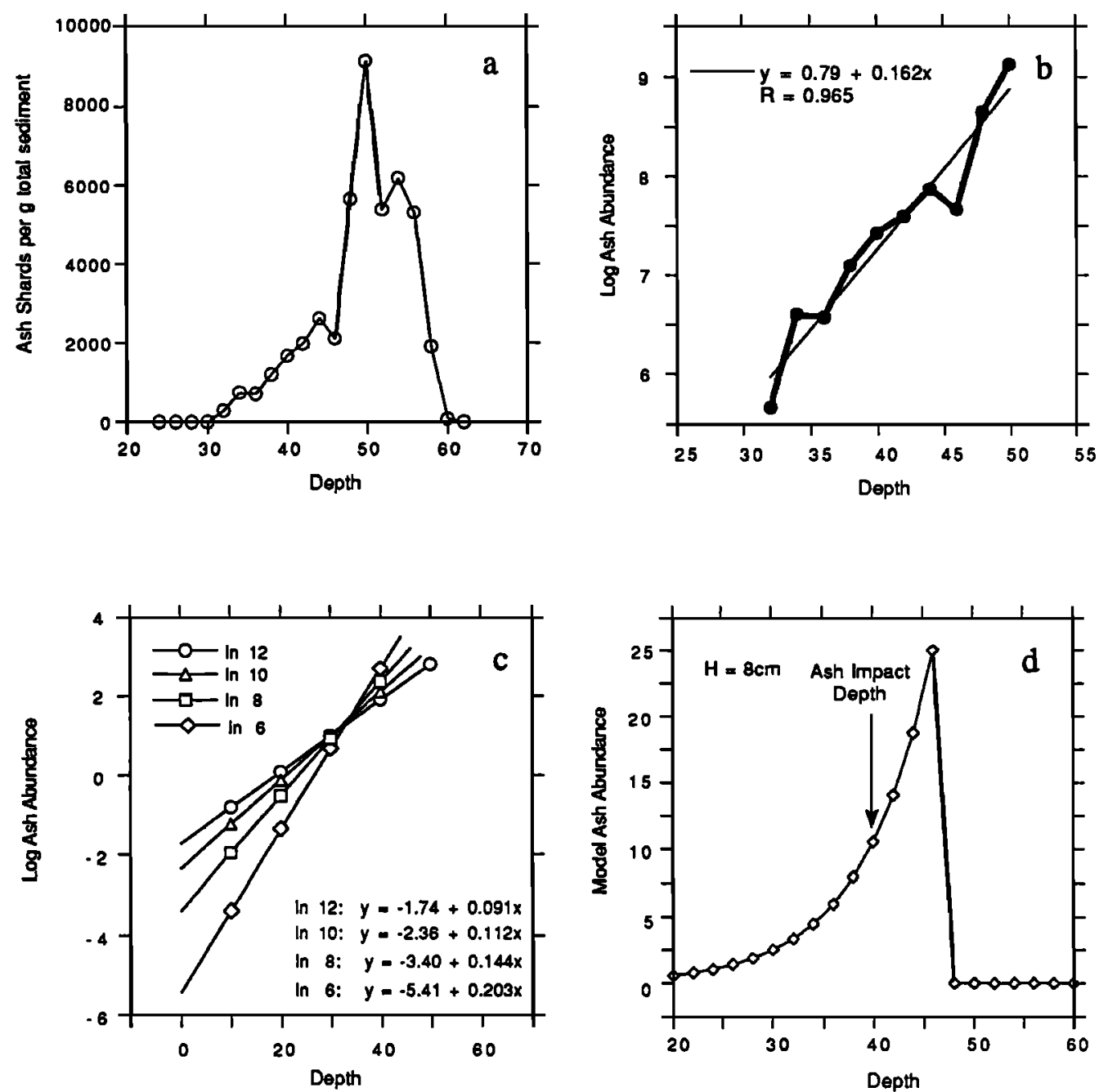

Figure 4. (a) Number of clear (rhyolitic) ash shards $>63 \mu \mathrm{m}$ per gram of total sediment with depth in core 5K. (b) Natural logarithm of the ash abundance with depth in core 5K. (c) Natural log of theoretical abundance profiles following bioturbation with different values of $H$.The profile for $H=8 \mathrm{~cm}$ most closely resembles the observed log abundance curve in Figure 4b. (d) Model bioturbation of an ash layer with $H=8$ $\mathrm{cm}$, displacing the ash peak downward from the original impact depth.

of very low measured abundance, the deconvolution actually yielded negative species abundance values. To facilitate the modeling these were altered to $0.01 \%$.

The offset between the originail (or "true") age and each of the "bioturbated" models is illustrated in Figure 6. This shows that ages recorded by $N$. pachyderma (s) in Holocene sediment $(0-50 \mathrm{~cm})$ would be far greater than the true age, due to the very low abundance of this species following the termination. It is most unlikely, though, that dating would ever be carried out on $N$. pachyderma (s) over this time interval, when there are many other species of greater abundance available. Across the transition from glacial to Holocene, however, species abundances are more variable, and the ages measured on $N$. pachyderma (s) and $G$. bulloides depart quite markedly from each other around $55-75 \mathrm{~cm}$, close to the termination as recorded in oxygen isotopes. The difference between them is up to 2500 years, with $N$. pachyderme (s) older than G. bulloides, which is similar to the offset observed in AMS dates for core $5 \mathrm{~K}$ at $74 \mathrm{~cm}$. The maximum age offset observed in the model occurs at slightly shallower depths than in the 5K AMS data (66 cm compared to $74 \mathrm{~cm}$ ), but this may be partly due to the simplicity of the assumed original age model. In reality, sedimentation rates probably varied from glacial to Holocene times.

The abundance of components other than foraminifera also changed from glacial to Holocene times, and the ages recorded by these components may be offset from those of foraminifera or other constituents with which they are mixed. In particular, the fine carbonate $(<10 \mu \mathrm{m})$ associated with coccoliths varies from around 80 to less than $40 \%$ by weight of the total sediment in core 5K. The effect of this upon ages that might be measured on the fine carbonate fraction is shown in Figure 6. The model assumes that bioturbation of the fines occurs in the same manner and to the same extent as for the sand fraction. Maximum offset is observed, as expected, at the transition from glacial to Holocene, occurring between 60 and 


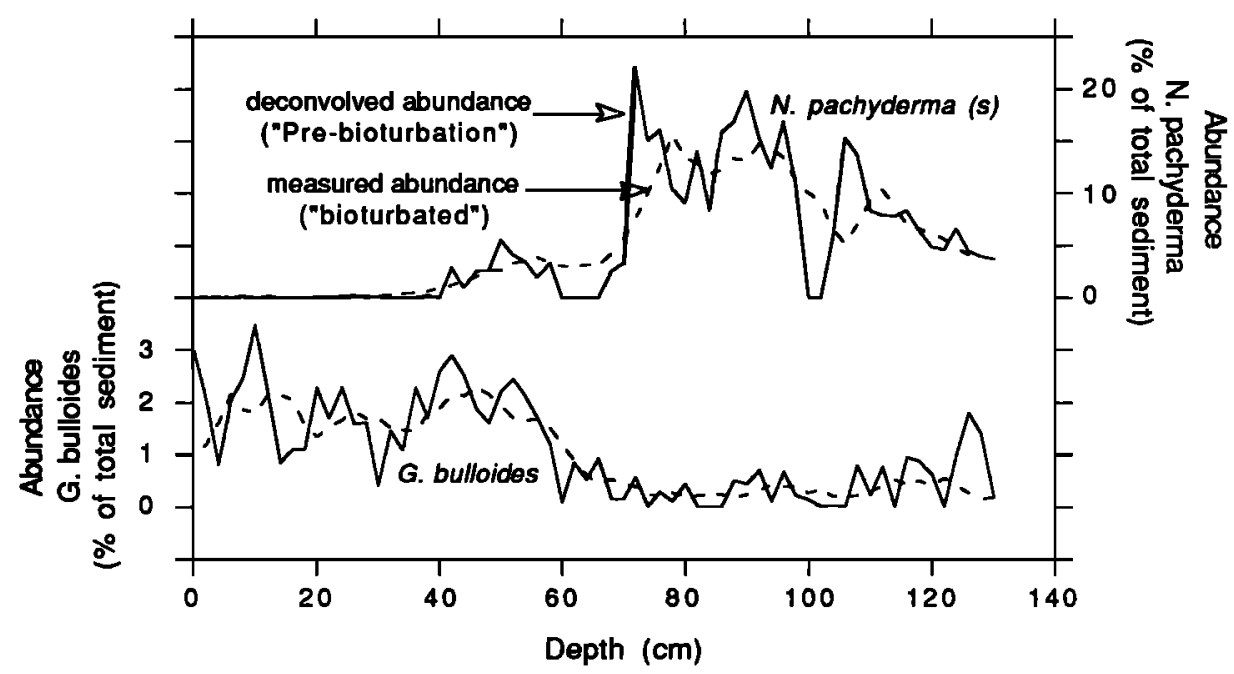

Figure 5. Measured and deconvolved abundances of the foram species $G$. bulloides and $N$. pachyderma (s). Abundances are expressed as weight percentage of the total sediment. The deconvolution was made using a bioturbation depth $H$ of $8 \mathrm{~cm}$ and a sampling interval of $2 \mathrm{~cm}$.

$80 \mathrm{~cm}$, but is only about 300 years greater than the true age.

Vertical biodiffusivity may be size-dependent, such that larger particles are less deeply mixed, and evidence suggests that the diffusivity of $250 \mu \mathrm{m}$ sand is about a factor of 10 less than $10 \mu \mathrm{m}$ silt [Wheatcroft, 1992]. In the simple bioturbation model used in this work, diffusion is regarded as operating infinitely fast with respect to the sedimentation rate. All size fractions would therefore record similar ages, provided no abundance gradients exist between them, even if the value of $\boldsymbol{H}$ varied with size. In reality, though, rates of deposition may be fast enough to preserve diffusional gradients [e.g. Guinasso and Schink, 1975, Schiffelbein, 1985]. This means that for the same sedimentation rate, different size fractions may be mixed to different depths (finer, deeper), causing age offsets between them, apparently independent of abundance gradients. Age discrepancies between size fractions have been documented by Paull et al. [1991] in cores from the subtropical Atlantic, and have also been noted in BOFS box cores (J. Thomson et al., submitted manuscript, 1995), although Ruddiman et al. [1980] found no evidence for a size-dependence for bioturbation of size fractions between 10 and $250 \mu \mathrm{m}$.

\section{Correlation Between Cores}

Following completion of the AMS-based age model for core $5 \mathrm{~K}$, the final stage is to make correlations between $5 \mathrm{~K}$ and the other cores from the suite, assigning ${ }^{14} \mathrm{C}$ and

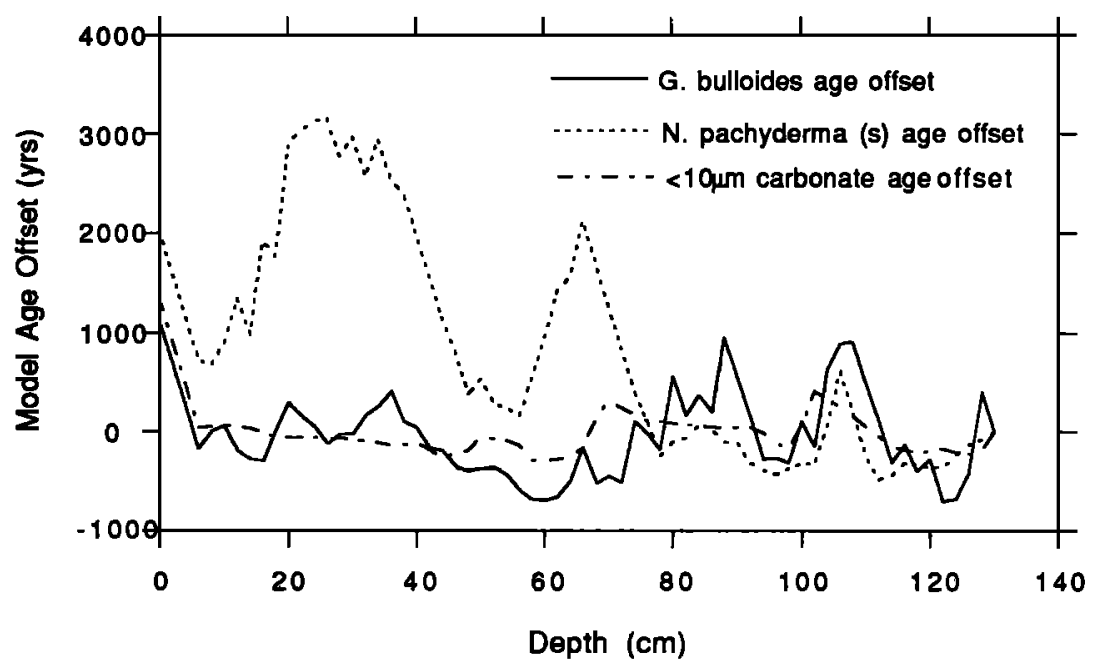

Figure 6. Offset between the model (linear) age and bioturbated ages recorded by G. bulloides, $N$. pachyderma (s) and fine $(<10 \mu \mathrm{m})$ carbonate, based upon measured abundance profiles. The maximum offsets occur in the transition from glacial to Holocene, around $60-80 \mathrm{~cm}$ depth, where gradients in abundance are most pronounced. 
"calendar" ages, and interpolating between the dated points. Correlation is effected on the basis of "landmarks" in downcore properties. Because the material is bioturbated, a landmark in one property (e.g. $\delta^{18} \mathrm{O}$ on sand-sized foraminifera) may not correspond in age to that of another (e.g. silt and clay fraction $\mathrm{CaCO}_{3}$ content). Additionally, "lithological", "biological" or "chemical" equivalence does not necessarily guarantee chronological correlation. AMS dating of core $5 \mathrm{~K}$ was carried out on the large forams $(250-350 \mu \mathrm{m})$, and the age model is therefore most directly applicable to the medium sand fraction $(250-500 \mu \mathrm{m})$.

\section{Oxygen and Carbon Isotopes}

Oxygen and carbon isotopic measurements were made on two species of planktonic foraminifera, $G$. bulloides and $N$. pachyderma (s), from five of the BOFS cores, $5 \mathrm{~K}, 8 \mathrm{~K}$, $11 \mathrm{~K}, 14 \mathrm{~K}$ and $17 \mathrm{~K}$. The most readily identifiable event in the profiles is the transition in $\delta^{18} \mathrm{O}$ from heavy to light values corresponding to Termination $1 \mathrm{~A}$. As a result of gradients in species abundance, discussed earlier, the precise position of this event differs between species, with the $G$. bulloides termination occuring at a deeper level, making it important to compare the same species. The base of Termination $1 \mathrm{~A}$ as defined in $G$. bulloides of core $x$ will not be time equivalent to the base defined in $N$. pachyderma (s) from core $y$. Correlation of the $\delta^{18} \mathrm{O}$ G. bulloides profiles is shown in Figure 7, and details are given in Table 3. The core top value of $\delta^{18} \mathrm{O}$ varies between sites in a systematic way, reflecting a north-south temperature gradient across the area (from $12.2^{\circ} \mathrm{C}$ at site $14 \mathrm{~K}$ to $16.8^{\circ} \mathrm{C}$ south of site $5 \mathrm{~K}$ [Lunel, 1990]). In core $14 \mathrm{~K}$, the sedimentation rate is sufficiently slow (average $1.64 \mathrm{~cm} \mathrm{ka}^{-1}$ ) and the core sufficiently long $(224 \mathrm{~cm})$ that the stratigraphy extends back to the stage $5 \mathrm{e} / 6$ boundary or Termination 2 . This event is assigned an age of 128,000 years [ $1 \mathrm{mbrie}$ et al., 1984].

In the case of carbon, the surface water ${ }^{13} \mathrm{C} /{ }^{12} \mathrm{C}$ ratio incorporated into the planktonic foram test will depend upon the degree to which organic production has depleted the ${ }^{12} \mathrm{C}$. This may be affected by the position of the polar front and could lead to downcore variations that are not synchronous across the area. The incorporation of metabolic $\mathrm{CO}_{2}$ into the test by some species can also lead to disequilibrium with respect to seawater $\mathrm{\Sigma CO}_{2}$ [Erez, 1978]. In general, oxygen isotopes are preferred over carbon isotopes for correlation purposes, but $\delta^{13} \mathrm{C}$ may provide support for correlations established in other measured properties.

\section{X-Radiography}

The BOFS cores benefit from $\mathrm{X}$ radiographs taken on board ship which reveal internal structure, and provide a good means of identifying turbidites, repenetration of the core barrel or evidence of discontinuous or disturbed sedimentation. A number of horizons appear to be directly correlatable between cores, showing up as dark, $\mathrm{X}$ ray opaque bands, commonly

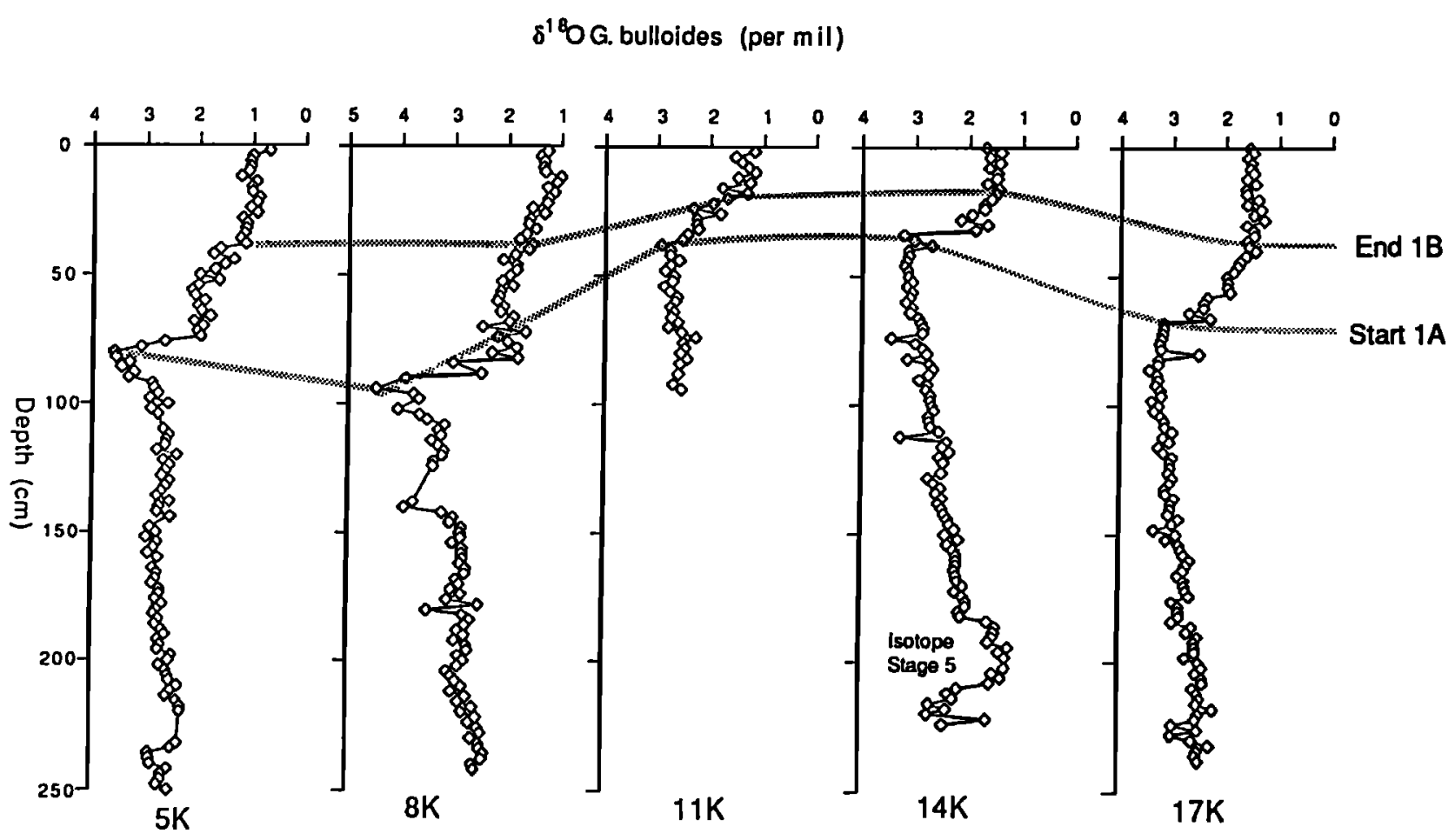

Figure 7. $\delta^{18} \mathrm{O}$ with depth measured on $G$. bulloides in cores $5 \mathrm{~K}, 8 \mathrm{~K}, 11 \mathrm{~K}, 14 \mathrm{~K}$ and $17 \mathrm{~K}$, showing the correlation at the start of Termination $1 \mathrm{~A}$. The core top values vary systematically with latitude, reflecting the fall in surface water temperature northward across the BOFS area. 


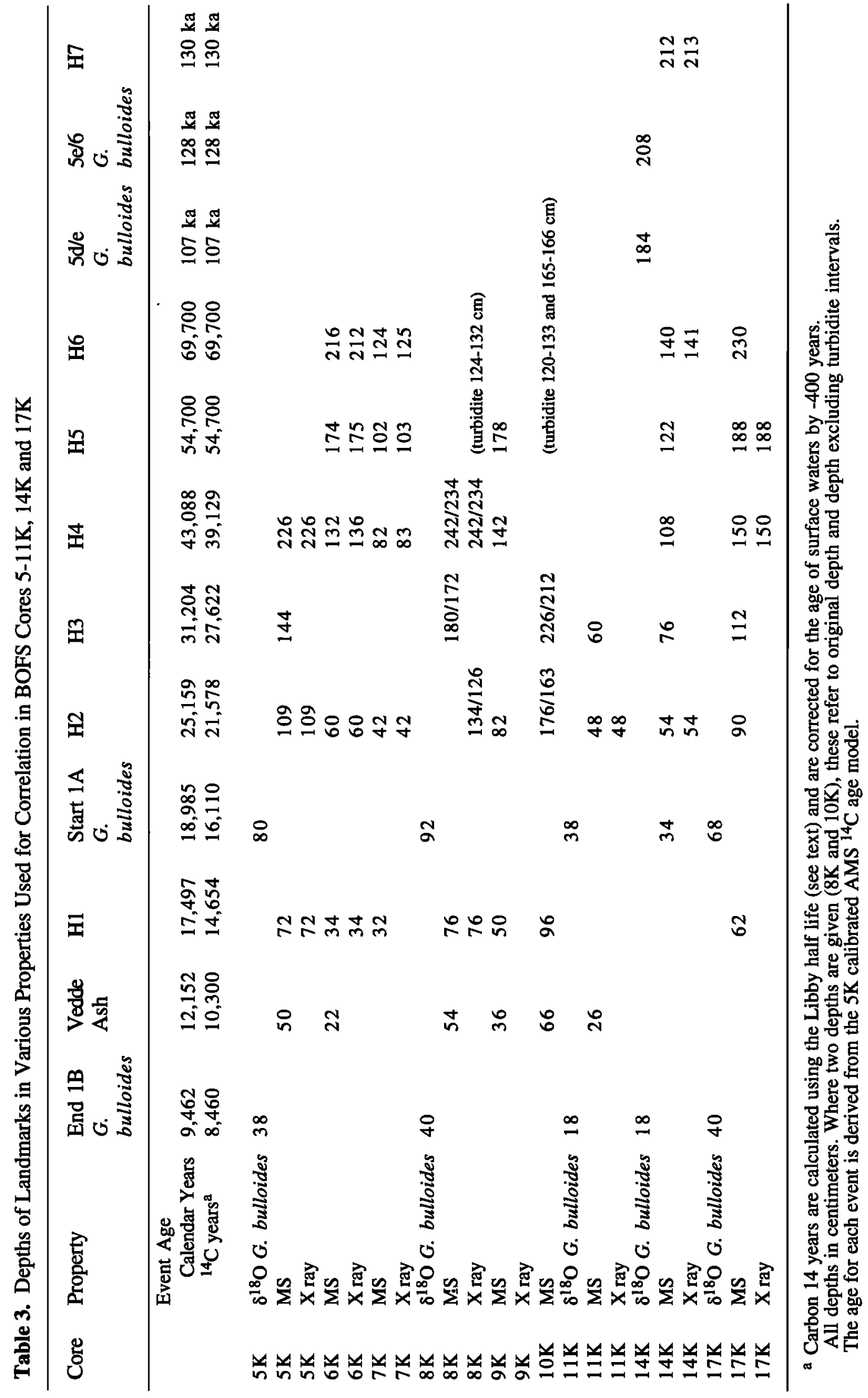


with sharp bases and gradational tops. In the core descriptions, it is clear that they correspond to gravel-rich layers, sometimes several centimetres thick, which represent peaks of ice-rafted detritus ("Heinrich layers" [Heinrich, 1988; Broecker et al., 1992]).

\section{Dating of Helnrlch Events}

The Heinrich layers are visible in $X$ radiographs because of the high proportion of relatively dense lithic fragments, decreasing the water content and rendering the sediment opaque to $\mathrm{X}$ rays. Deposition of this material probably took place during basin-wide "events" which were essentially synchronous throughout the BOFS area. The layers are therefore considered a reliable basis for true time correlation. The quantity and coarseness of the ice-rafted detritus make it unlikely that their positions could be substantially altered by bioturbation, although upward dispersal and secondary layers may occur as noted by $M c$ Cave [1988]. The layers thus present an interesting temporary "block" in the bioturbation process with the hemipelagic sediment immediately above a layer containing little or no older material from below it. This preserves a fossil mixed layer below each Heinrich zone, and means that an attempt to date the event by sampling forams immediately below it may give misleading results. Even without the presence of species abundance gradients, the foraminiferal age immediately below would be too old by the age of the mixed layer (Figure 8). However, the dramatic drop in foraminiferal abundance which took place during the ice- rafting events is also likely to cause a bias in the age record from forams above the Heinrich layers. These would tend to be younger than the bulk sediment age for some distance above each event.

By interpolation between AMS dates in core $5 \mathrm{~K}$, the ages assigned to the first four Heinrich events are $17,500,25,150$, 31,200 and 43,100 calendar years, (corresponding to atmospheric ${ }^{14} \mathrm{C}$ ages of $14,654,21,578,27,622$ and 39,129 years, respectively). The earlier Heinrich events, 5, 6 and 7 (peak 11 of Heinrich, [1988]) are outside the scope of the 5K AMS age model, but have been dated by other workers via extrapolation of ${ }^{14} \mathrm{C}$-AMS-based sedimentation rates [Bond et al. 1992; 1993] and by interpolation between oxygen isotope events [Heinrich, 1988; Broecker et al., 1992; Grousset et al., 1993]. If the atmospheric ${ }^{14} \mathrm{C}$ age for Heinrich peak 4, determined from the $5 \mathrm{~K}$ AMS model, is incorporated into the model for core $14 \mathrm{~K}$, interpolation between it and the stage $5 \mathrm{e} / 6$ boundary yields ages for peaks H5 and H6 of 51,300 and 67,000 years. These closely resemble the values obtained by Bond et al. [1992], (52,000 and 69,000) and Broecker et al. [1992] $(50,000$ and $60,000-70,000)$. However, if the "calibrated" age of $\mathrm{H} 4$ is used instead, the ages for peaks H5 and $\mathrm{H} 6$ become 54,700 and 69,700. The age of the oldest Heinrich layer recovered in core $14 \mathrm{~K}$ is estimated at 130,000 , because of its position immediately below the stage $5 \mathrm{e} / 6$ boundary. These ages are used to construct portions of age models extending beyond the range of core 5K. In Table 3 the correlations between cores based upon the position of icerafting peaks visible in the $\mathrm{X}$ radiographs are given.
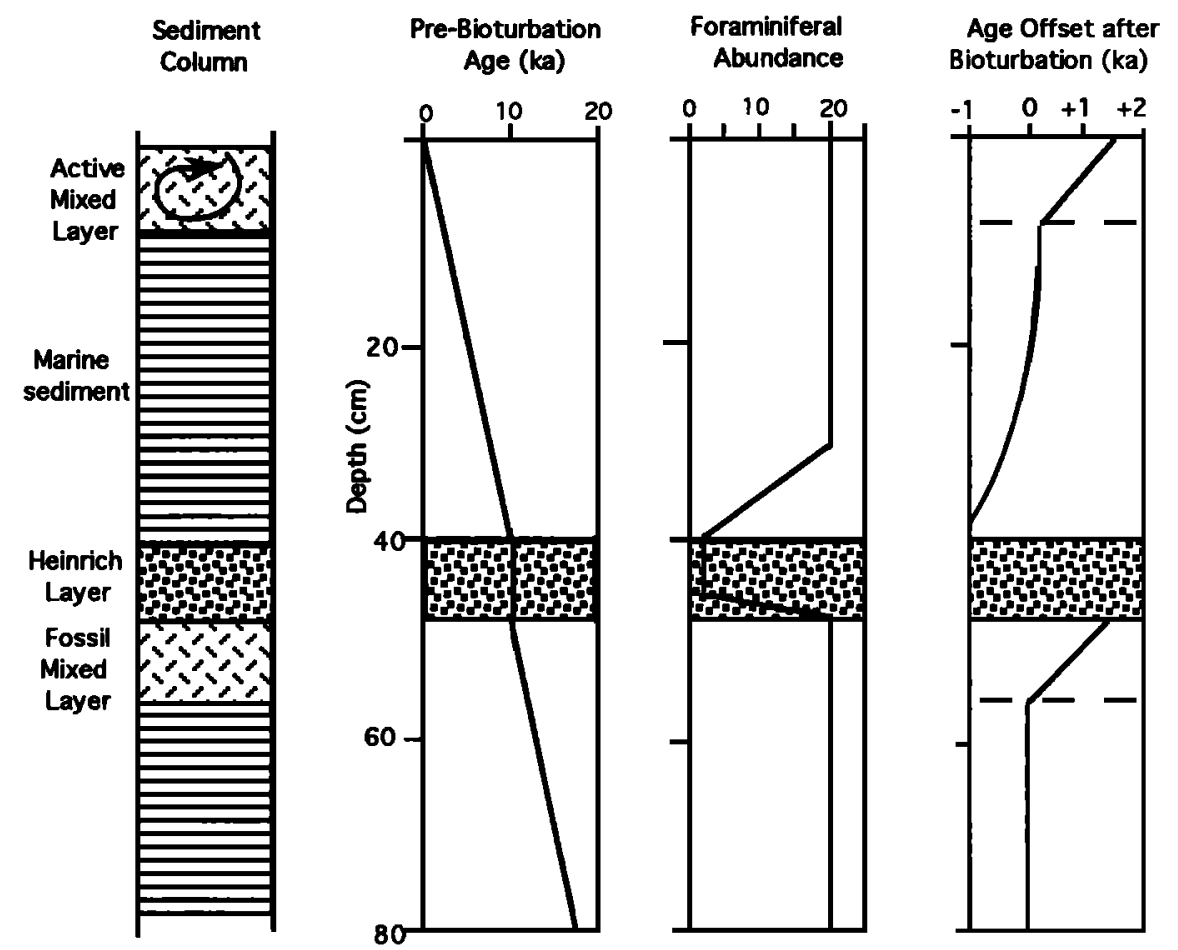

Figure 8. Simple model demonstrating the age offsets which may occur above and below Heinrich layers, as a result of blocking the bioturbation process. A fossil mixed layer is preserved beneath the icerafted detritus, in which ages of foraminifera tend to be older than pre-bioturbation values. Above the Heinrich zone, foraminiferal ages will are younger than pre-bioturbation values, as a result of homogenization of a new mixed layer. 


\section{Magnetic Susceptlbility and Water Content}

Measurements of bulk magnetic susceptibility (BMS) were made on fresh sediment slabs following $X$ radiography (Figure 9) and on coarse and fine fractions after drying. The most prominent features of the BMS profiles correspond to the icerafting pulses, which delivered a quantity of lithic material of diverse mineralogy to the sea bed. In some cases, peaks of ice rafting may be identified in BMS which do not show up on the $X$ radiographs. In Figure 9, the more southerly cores, 5, 6 and $7 \mathrm{~K}$, show the most marked expression of the ice-rafting pulses. Some of these events are more obvious than others in BMS with peak "H3" (Heinrich layer 3) being absent in many profiles. In addition to these events, a minor increase in BMS is often observed at the depth of the Vedde Ash, and provides a guide to recognition of the ash in the coarse fraction microscopically.

Where doubt exists over the exact location of a peak, water content measurements can sometimes help to refine the choice of position. At 4-cm intervals, however, the measurements are too widely spaced to be of much value for correlation in cores with low sedimentation rates. The Heinrich layers as seen in

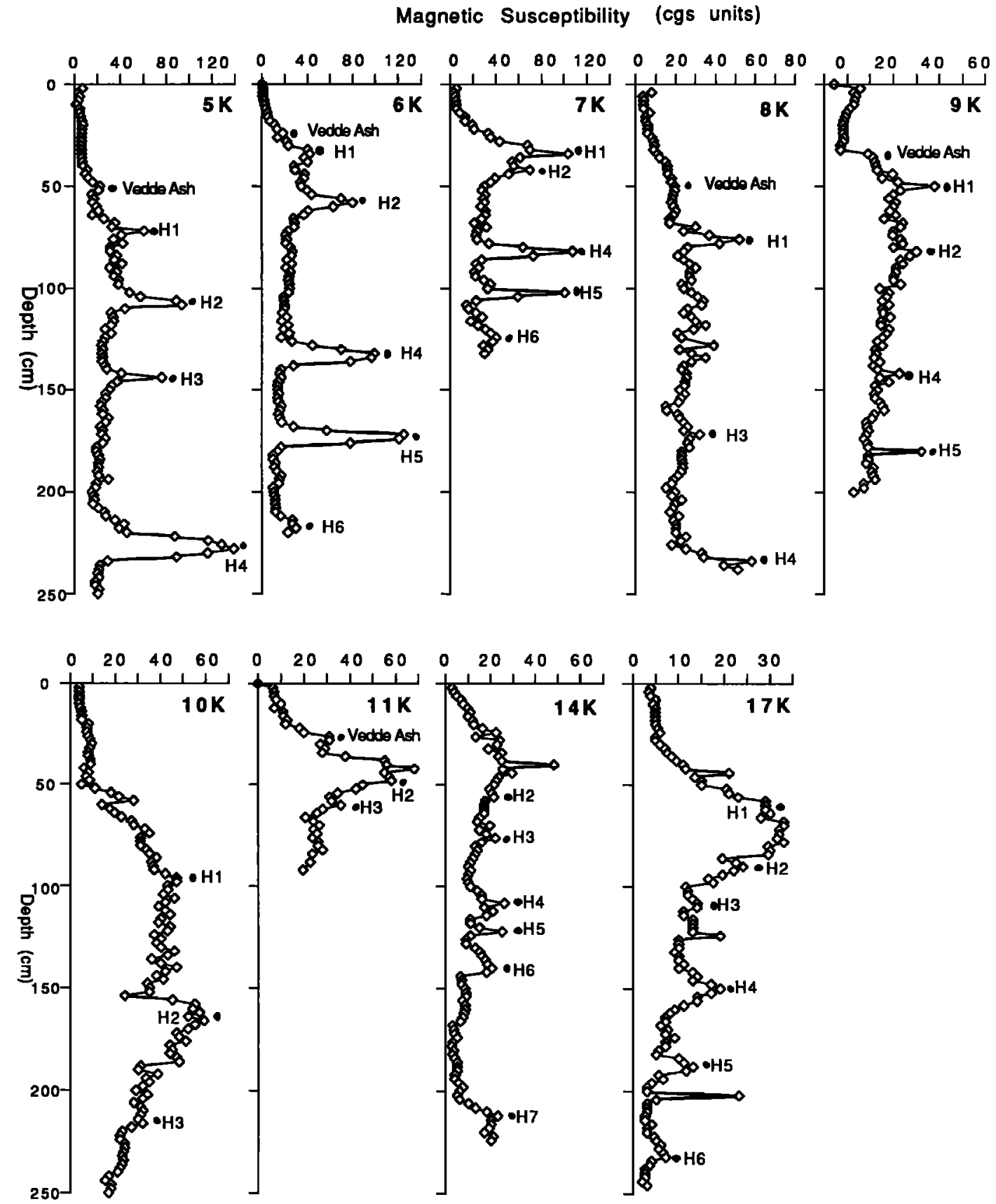

Figure 9. Bulk magnetic susceptibility with depth in the nine BOFS cores studied. The most prominent horizons for correlation are the peaks corresponding to Heinrich layers, which are marked H1-H7. 
the $X$ radiographs are often only 1 or $2 \mathrm{~cm}$ thick, and may be missed entirely by this sampling strategy.

\section{Carbonate Content}

Carbonate (or inorganic carbon present in $\mathrm{CaCO}_{3}$, expressed as $C_{i}$ ) is predominantly a measure of the amount of biogenic carbonate from whole and fragmented foraminiferal tests and coccolith remains present in the sediment. Detrital carbonate also occurs as lithic fragments amongst the icerafted material deposited during Heinrich events. In general, the $C_{i}$ profiles are characterized by low levels during the glacial ( $\left.1-4 \% \mathrm{C}_{i}\right)$ and values increase rapidly around Termination $1 \mathrm{~A}$ to high levels in the Holocene $\left(8-10 \% \mathrm{C}_{i}\right)$ [Manighetti and McCave, this issue]. Carbonate content is a function not only of biogenic productivity, but also of dissolution and dilution by terrigenous material. Because there are so many influences upon it, this property may be difficult to correlate with confidence. Spatial variation in water temperature, ice cover, depth, and proximity to sources of terrigenous input will all affect the levels of carbonate in the cores. In addition, the architecture of the profiles is insufficiently distinctive over much of the record to provide more than a general guide to correlation in the short term. No points have been correlated solely on the basis of $\mathrm{C}_{i}$, but similarities have been used as supporting evidence for correlations in other properties.

\section{Ash Correlation}

For correlation purposes, the presence of ash peaks is often considered a means of establishing reliable chronological tie points across a suite of cores. In the northeast Atlantic, the Vedde Ash peak is usually assigned a ${ }^{14} \mathrm{C}$ (atmospheric) age of 10,600 years [Mangerud et al., 1984]. This age has been recently revised to around 10,300 years [Bard et al., 1993b], which corresponds to a calibrated age of 12,152 years. However, as demonstrated earlier, the position of the peak of ash abundance will have been moved downward by homogenous bioturbation, perhaps by $8 \mathrm{~cm}$ or more, and will lie among foraminifera recording an older age, depending upon the sedimentation rate. Since the sedimentation rates in the BOFS cores vary from less than 2 to more than $10 \mathrm{~cm} \mathrm{ka}^{-1}$, identification of the ash does not guarantee chronological correlation. In fact, the ash is most unlikely to be mixed to similar age levels in all cores. It may be more accurate to correct for differential sedimentation rate by assuming that homogenous bioturbation affects all cores to a similar depth, then assigning a ${ }^{14} \mathrm{C}$ age of $10,300(12,152$ calendar years) to the interval $6-8 \mathrm{~cm}$ above the peak of ash abundance. This approach was adopted in the development of age models for the BOFS cores. The positions of the ash peaks are given in Table 3.

\section{Conclusions}

The objective of this study has been to document the series of observations, measurements, calculations and assumptions involved in the construction of age models for the BOFS cores. We have constructed a calibrated AMS ${ }^{14} \mathrm{C}$ model for core $5 \mathrm{~K}$ based mainly on $G$. bulloides and $N$. pachyderma (s) dates, which minimizes the effect of bioturbation of abundance gradients on age. A simple homogenous bioturbation model has been used with different mixing depths to assess the age offsets generated by such gradients. We find possible differences of $2.5-3 \mathrm{ka}$ between the two species across Termination $1 \mathrm{~A}$, with mixing depths of $8-10 \mathrm{~cm}$. G. bulloides ages are least biased during the Holocene, whereas $N$. pachyderma (s) dates are good below Termination 1A. The age of fine carbonate $(<10 \mu \mathrm{m})$ should show only minor offsets from "unbioturbated" ages, provided that the material is of primary biogenic and not detrital origin. The mixing depth for core $5 \mathrm{~K}$ was assessed by examining dispersal of the Vedde Ash, and a value of roughly $8 \mathrm{~cm}$ was found to be characteristic of sand-sized material.

Extension of the core $5 \mathrm{~K}$ model to other cores in the suite was achieved by correlation of landmarks in $\delta^{18} \mathrm{O}$, magnetic susceptibility, $X$ radiography, $\delta^{13} \mathrm{C}$, and ash layers, assisted by carbonate-carbon and water content data. Heinrich zones were recognised and dated at $17,500,25,150,31,200$, $43,100,54,700,69,700$ and 130,000 (all consistently calendar years). Dating of these events is hampered by the strong abundance gradients associated with them, and the blocking effect they have upon bioturbation.

Acknowledgements. We thank David Page and Mike Hall for assistance with foram picking and isotopic analyses and Gillian Foreman for sedimentology. Perceptive discussions with Mark Hallworth and John Thomson were of great benefit in developing the ideas presented here, and we are grateful to J. Thomson and E. Bard for their reviews. This research was supported by NERC grant GST/02/436. BOFS publication \# 197.

\section{References}

Andree, $\mathrm{M}$., et al., ${ }^{14} \mathrm{C}$ measurements on foraminifera of deep sea core V28-238 and their preliminary interpretation, Nucl. Instrum. Methods Phys. Res., Sect. B, 5, 340-345, 1984.

Bard, E., M. Amold, J. Duprat, J. Moyes and J.-C. Duplessy, Reconstruction of the last deglaciation: Deconvolved records of $\delta^{18} \mathrm{O}$ profiles, micropaleontological variations and accelerator mass spectrometric ${ }^{14} \mathrm{C}$ dating, Clim. Dyn., 1, 101-112, 1987.

Bard, E., M. Amold, R. G. Fairbanks and B. Hamelin, ${ }^{230}{ }_{\mathrm{Th}-}{ }^{234} \mathrm{U}$ and ${ }^{14} \mathrm{C}$ ages obtained by mass spectrometry on corals, Radiocarbon, 35 , 191-199, 1993a.

Bard, E., M. Amold, J. Mangerud, M. Pateme, L. Labeyrie, J. Duprat, M. A. Melieres and E. Sonstegaard, Past gradients of the atmosphere-sea surface ${ }^{14} \mathrm{C}$ gradient. Example of the North Atlantic during the Younger Dryas climatic event. Terra Abstr. 5 , 14, paper presented at EUG VII Strasbourg, France, April 4-8 , 1993b.

Berger, W. H. and G. R. Heath Vertical mixing in pelagic sediments, $J$. Mar. Res., 26: 134-143, 1968.

Bond, G., et al., Evidence for massive discharges of icebergs into the North Atlantic ocean during the last glacial period, Nature, 360, 245249, 1992.

Bond, G., W. Broecker, S. Johnsen, J. McManus, L. Labeyrie and G. Bonani, Correlations between climate records from North Atlantic sediments and Greenland ice, Nature, 365, 143-147, 1993.

Broecker, W., A. Mix, M. Andree and H. Oeschger, Radiocarbon measurements on coexisting benthic and planktic foraminifera shells: potential for reconstructing ocean ventilation times over the past 20,000 years., Nucl. Instrum. Methods Phys., Sect. B, 5, 331$339,1984$. 
Broecker, W. S., M. Andree, W. Wolfli, H. Oeschger, G. Bonani, J. Kennett and D. Peteet, The chronology of the last deglaciation: Implications to the cause of the Younger Dryas event. Paleoceanography, 3, 1-19, 1988.

Broecker, W., G. Bond, M. Klas, E. Clark and J. McManus, Origin of the northern Atlantic's Heinrich events, Clim. Dyn., 6, 265-273, 1992.

Erez, J.,. Vital effect on stable isotopic composition seen in foraminifera and coral skeletons, Nature, 273, 199-202, 1978.

Grousset, F. E., L. Labeyrie, J. A. Sinko, M. Cremer, G. Bond, J. Duprat, E. Cortijo and S. Huon, Pattems of ice rafted detritus in the glacial North Atlantic $\left(40-45^{\circ} \mathrm{N}\right)$, Paleoceanography, 8, 175-192, 1993.

Guinasso, N. L. and D. R. Schink, Quantitative estimates of biological mixing rates in abyssal sediments, J. Geophys. Res., 80, 3032-3043, 1975.

Heinrich, H., Origin and consequences of cyclic ice rafting in the northeast Atlantic Ocean during the past 130,000 years, Quat. Res., 29, 143-152, 1988.

Imbrie, J., J. D. Hays, D. G. Martinson, A. McIntyre, A. C. Mix, J. J. Morley, N. G. Pisias, W. L. Prell and N. J. Shackleton, The orbital theory of Pleistocene climate: Support from a revised chronology of the marine $\delta^{18} \mathrm{O}$ record, in Milankovitch and Climate, edited by $\mathrm{A}$. L. Berger et al., pp. 269-305, D. Reidel, Norwell, Mass., 1984.

Jones, K. P. N., I. N. McCave and P. D. Patel, A computer-interfaced sedigraph for modal size analysis of fine-grained sediment, Sedimentology, 35, 163-172, 1988.

Kipp, N., New transfer function for estimating past sea surface conditions from sea bed distribution of planktonic foraminiferal assemblages in the North Atlantic, Geol. Soc. Am. Mem., 145, 3-41, 1976.

Lunel, T., Trace metal concentrations and isotopes as tracers of oceanic processses, Ph.D. thesis., 169pp., Univ. of Cambridge, Cambridge, England, 1990.

Mangerud, J., S. E. Lie, H. Fumees, I. L. Kristiansen and L. Lomo, A Younger Dryas ash bed in Western Norway, and its possible correlations with tephra in cores from the Norwegian Sea and the North Atlantic, Quat. Res., 21, 85-104, 1984.

Manighetti, B., The glacial to Holocene sedimentary regime in the northeast Atlantic Ocean, Ph.D. thesis, 218pp., Univ. of Cambridge, Cambridge, England, 1993.

Manighetti, B. and I. N. McCave, Depositional fluxes, palaeoproductivity and ice rafting in the NE Atlantic over the past $30 \mathrm{ka}$. Paleoceanography, this issue.

Maslin M.A., A study of the palaeoceanography of the NE Atlantic in the Late Pleistocene, Ph.D thesis, 164 pp., Univ. of Cambridge, Cambridge, England, 1993.

McCave, I. N., Leg 3, Benthic Studies, of the Biogeochemical Ocean Flux Study between $47^{\circ} \mathrm{N}$ and $60^{\circ} \mathrm{N}$ along $20^{\circ} \mathrm{W}$ in the northeast Atlantic Ocean, cruise report, Univ. of Cambridge, Cambridge, England, 1989.

McCave, I. N., Biological pumping upwards of the coarse fraction of deep-sea sediments. J. Sedimentol. Petrol., 58, 148-158, 1988.

Nozaki, Y., J. K. Cochran, K. K. Turekian and G. Keller, Radiocarbon and ${ }^{210} \mathrm{~Pb}$ distribution in submersible-taken deep-sea cores from project FAMOUS, Earth Planet. Sci. Lett., 34, 167-173, 1977.

Paull, C. K., S. J. Hills, H. R. Thierstein, G. Bonani and W. Wolfli, ${ }^{14} \mathrm{C}$ offsets and apparently non-synchronous $\delta^{18} \mathrm{O}$ stratigraphies between nannofossil and foraminiferal pelagic carbonates, $Q$ uat. Res., 35, 274-290, 1991.

Peng, T. -H. and W. S. Broecker, The impacts of bioturbation on the age difference between benthic and planktonic foraminifera in deep sea sediments., Nucl. Instrum. Methods Phys. Res., Sect. B, S, 346$352,1984$.

Peng, T. -H., W. S. Broecker, G. Kipphut and N. J. Shackleton, Benthic mixing in deep sea cores as determined by ${ }^{14} \mathrm{C}$ dating and its implications regarding climate stratigraphy and the fate of fossil fuel $\mathrm{CO}_{2}$, in The Fate of Fossil Fuel $\mathrm{CO}_{2}$ in the ocean, edited by $\mathrm{N}$. Andersen and A. Malahoff, pp. 355-374, Plenum, New York, 1977.

Ruddiman, W. F. and A. McIntyre, Northeast Atlantic paleoclimatic changes over the past 600,000 years, Geol. Soc. Am. Mem., 145, 111-146, 1976.

Ruddiman, W. and A. McIntyre, The North Atlantic ocean during the last deglaciation, Palaeogeogr. Palaeoclimatol. Palaeoecol., 35. 145-214, 1981.

Ruddiman, W. F., C. D. Sancettta and A. McIntyre, Glacial/Interglacial response rate of subpolar North Atlantic waters to climatic change: the record in oceanic sediments, Philos. Trans. R. Soc. London, Ser. $B, 280,119-142,1977$.

Ruddiman, W. F., G. A. Jones, T. H. Peng, L. K. Glover, B. P. Glass and P. J. Liebertz, Tests for size and shape dependency in deep-sea mixing, Sediment. Geol., 25, 257-276, 1980.

Schiffelbein, P., Extracting the benthic mixing impulse response function: A constrained deconvolution technique, Mar. Geol., 64, 313-336, 1985.

Shackleton, N. J. and M. A. Hall, Stable isotope history of the Pleistocene at ODP site 677, Proc. Ocean Drill. Program, Sci. Results, 111, 295-316, 1989.

Stuiver, M. and P. J. Reimer, Extended ${ }^{14} \mathrm{C}$ data base and revised calib 3.0 ${ }^{14} \mathrm{C}$ age calibration program, Radiocarbon, 35, 215-230, 1993.

Stuiver, M. and T. F. Braziunas, Modelling atmospheric ${ }^{14} \mathrm{C}$ influences and ${ }^{14} \mathrm{C}$ ages of marine samples back to $10,000 \mathrm{BC}$, Radiocarbon, 35, 137-189, 1993

Thomson, J., S. Colley, R. Anderson, G. T. Cook and A. B. MacKenzie, ${ }^{210} \mathrm{~Pb}$ in the sediments and water column of the Northeast Atlantic from $47-59^{\circ} \mathrm{N}$ along $20^{\circ} \mathrm{W}$, Earth Planet. Sci. Letts., 115, 75-87, $1993 \mathrm{a}$.

Thomson, J., S. Colley, R. Anderson, G. T. Cook, A. B. MacKenzie and D. D. Harkness, Holocene sediment fluxes in the Northeast Atlantic from ${ }^{230} \mathrm{Th}$ excess and radiocarbon measurements, Paleoceanography, 6, 631-650, 1993b.

Wheatcroft, R. A., Experimental tests for particle size-dependent bioturbation in the deep ocean, Limnol. Oceanogr., 37, 90-104, 1992.

Zangger, E. and I. N. McCave, A redesigned kasten core barrel and sampling technique, Mar. Geol., 94, 165-171, 1990.

B. Manighetti and I. N. McCave, Department of Earth Sciences, University of Cambridge, Downing Street, Cambridge, CB2 3EQ England.(e-mail B. Manighetti@esc. cam. ac. uk)

M. Maslin, Geologisch-Palaontologisches Institut, Universitat Kiel, Kiel, Germany.

N. J. Shackleton, Godwin Laboratory, University of Cambridge, Free School Lane, Cambridge, CB2 3RS, England.

(Received November 23, 1994; revised June 20, 1994; accepted November 16, 1994.) 